\title{
Urgensi Nilai Taksiran terhadap Motivasi Nasabah dalam Transaksi Gadai Emas
}

\author{
Semawati \\ Institut Agama Islam Negeri (IAIN) Bone \\ semawatiiainbone@yahoo.cm
}

\author{
Asmarani \\ Sekolah Tinggi Agama Islam (STAl) Al -Furqan Makassar \\ Asmarani1979@gmail.com
}

\begin{abstract}
This study aims to determine whether the estimated value set by pawn service providers is one of the considerations for customers in pawning their gold and whether the estimated value plays an important role in motivating customers in gold pawning transactions at certain pawnshops. The results of the study show that 1) Estimated value is a consideration for customers to pawn their gold at a pawnshop that has a high estimated value. But not only the estimated value is taken into consideration because some gold pawn customers choose a pawnshop to pawn gold based on relatively low maintenance costs. In this case, it proves that not only the estimated value that is taken into consideration, customers make gold pawning transactions but there are several other considerations such as maintenance costs. 2) The estimated value of gold plays an important role in motivating customers to pawn gold at a pawnshop because the estimated value is a reference for customers in obtaining loans.
\end{abstract}

Keywords: Urgency, Estimated Value, Customer Motivation, Gold Pawn

\begin{abstract}
Abstrak
Penelitian ini bertujuan untuk mengetahui apakah nilai taksiran yang ditetapkan lembaga penyedia jasa gadai menjadi salah satu pertimbangan bagi nasabah dalam menggadaikan emasnya dan apakah nilai taksiran berperan penting dalam memotivasi nasabah pada transaksi gadai emas di lembaga gadai tertentu. Hasil penelitian menunjukkan bahwa 1) Nilai taksiran menjadi pertimbangan bagi nasabah menggadaikan emasnya di lembaga gadai yang memiliki ketetapan nilai taksiran yang tinggi. Namun tidak hanya nilai taksiran yang menjadi pertimbangan karena beberapa nasabah gadai emas memilih lembaga gadai untuk menggadaikan emasnya berdasarkan biaya pemeliharaan yang relatif rendah. Dalam hal ini membuktikan bahwa bukan hanya nilai taksiran yang menjadi pertimbangan nasabah melakukan transaksi gadai emas tetapi ada beberapa pertimbangan lain seperti biaya pemeliharaan. 2) Nilai taksiran emas berperan penting dalam memotivasi nasabah untuk menggadaikan emas di lembaga gadai karena nilai taksiran menjadi acuan bagi nasabah dalam memperoleh pinjaman.
\end{abstract}

Kata Kunci: Urgensi, Nilai Taksiran, Motivasi Nasabah, Gadai Emas 


\section{PENDAHULUAN}

Kehidupan manusia tidak terlepas dari segala aktivitas yang membutuhkan pembiayaan, baik yang bersifat pribadi, kelompok, organisasi, dan kepentingan umum. Hal ini terjadi karena biaya dan kebutuhan manusia setiap hari meningkat seiring dengan perkembangan kebutuhan ekonomi dan perkembangan globalisasi. Peristiwa ini menyebabkan manusia kesulitan untuk memenuhi biaya kebutuhan yang bersifat produktif lebih-lebih konsumtif.

Gadai emas syariah merupakan jenis jasa pembiayaan baru dari perbankan syariah yang sebelumnya sudah dirintis oleh Pegadaian Syariah. Awalnya masyarakat mengetahui tempat untuk menggadaikan emas miliknya di Pegadaian saja. Kini masyarakat mulai menggunakan gadai emas pada perbankan syariah. Hal ini ditunjukkan banyaknya lembaga perbankan yang menawarkan gadai emas syariah seperti BRI Syariah, BNI Syariah, Bank Mega Syariah, BSM (Bank Syariah Mandiri). ${ }^{1}$ Dengan adanya persaingan seperti ini, maka Bank Syariah Mandiri, Pegadaian Syariah maupun lembaga usaha gadai lainnya melakukan beragam cara dan inovasi dalam produk gadai yang mereka hasilkan, khususnya pada nilai taksiran emas.

Nilai taksiran emas dapat menjadi tolok ukur nasabah untuk memilih menggadaikan emasnya di suatu lembaga gadai syariah. Beberapa lembaga keuangan yang berfokus pada usaha gadai memiliki ketetapan nilai taksiran emas tersendiri sebagai bentuk promosi mereka dalam menarik nasabah yang akan menggunakan jasa gadainya. Hal ini dapat dilihat dengan perbedaan ketetapan nilai taksiran di Bank Syariah Mandiri, Pegadaian, Pegadaian Syariah maupun lembaga usaha gadai lainnya. Nilai taksiran yang diberikan oleh Pegadaian Syariah yakni 92-95\% dari nilai taksiran emas. Berbeda dengan nilai taksiran yang diberikan Pegadaian konvensional yaitu 85\% dari harga emas. Nilai taksiran yang diberikan oleh BRI Syariah yakni pengambilan pinjaman maksimal 95\% untuk emas lantakan dan 90\% emas perhiasan. Terdapat pula penetapan nilai taksiran berkisar $\geq 100 \%$ yang diberikan oleh PT. Titipan Emas pada Unit Solusi Tunai. Sedangkan pada Bank Syariah Mandiri, pengambilan pinjaman

${ }^{1}$ Fitria Wari," Pengaruh Nilai Taksiran Emas terhadap Keputusan Nasabah Menggunakan Produk Gadai di Pegadaian Syariah Cabang Blauran Surabaya," Skripsi, Fakultas Ekonomis dan Bisnis Islam Universitas Islam Negeri Sunan Ampel, 2017, h. 3. 
maksimal $80 \%$ dari harga taksiran untuk perhiasan dan 95\% dari harga taksiran untuk logam mulia.

Nilai taksiran yang tinggi mampu mendorong keputusan nasabah menggunakan jasa gadai emas. Nasabah akan merespon positif apabila nilai yang dihasilkan dari produk dan jasa mampu memenuhi manfaat bagi kehidupannya. ${ }^{2}$ Hal seperti ini digunakan oleh lembaga gadai tentunya, karena semakin banyak nasabah melakukan gadai maka akan menambah omset bagi lembaga tersebut.

Seiring dengan peningkatan kebutuhan masyarakat terhadap pembiayaan mendorong masyarakat untuk melakukan transaksi gadai emas dalam memenuhi kebutuhan yang mampu memberikan kepuasan terhadap pemenuhan kebutuhan yang mampu memberikan kepuasan terhadap pemenuhan kebutuhan keuangan nasabah. Dengan demikian motivasi nasabah terhadap produk gadai emas sangatlah bervariasi tergantung paradigma masing-masing nasabah. Ada yang memilih gadai emas syariah karena mereka mendapatkan informasi melalui media social, karyawan, maupun kesadaran nasabah tentang gadai emas yang penerapan, mekanisme dan prosedur sangat mudah dilengkapi nilai taksiran yang memuaskan. Berdasarkan uraian tersebut, peneliti tertarik untuk meneliti urgensi nilai taksiran terhadap motivasi nasabah dalam transaksi gadai emas. Berdasarkan latar belakang diatas, maka pokok permasalahan yang dapat dirumuskan adalah sebagai berikut:

Apakah nilai taksiran yang ditetapkan oleh lembaga penyedia jasa gadai menjadi pertimbangan bagi nasabah dalam menggadaikan emasnya dan Apakah nilai taksiran berperan penting dalam memotivasi nasabah pada transaksi gadai emas di lembaga gadai tertentu.

\section{METODE}

1. Jenis Penelitian

Berdasarkan analisisnya, jenis penelitian yang digunakan adalah penelitian kualitatif.

${ }^{2}$ Rambat Lupiyoadi dan Hamdani, Manajemen Pemasaran Jasa, (Jakarta: Salemba Empat, 2009), h. 70-71. 
Karena jenis penelitian ini bisa memberikan data yang akurat dan spesifik terhadap objek penelitian. Adapun yang dimaksud dengan penelitian kualitatif adalah prosedur penelitian yang menghasilkan data dekskriptif berupa kata-kata tertulis atau lisan dari orang-orang atau perilaku yang dapat diamati. ${ }^{3}$

Berdasarkan jenis dan tujuannya, penelitian ini merupakan penelitian deskriptif- kualitatif. Deskriptif bertujuan untuk memberikan gambaran tentang suatu gejala tertentu. Kualittatif yaitu suatu penelitian yang bermaksud memahami fenomena tentang apa yang dialami oleh subjek penelitian secara holistic dan dengan cara deskripsi dalam bentuk kata-kata dan bahasa pasa suatu konteks yang alamiah serta dengan memanfaatkan berbagai metode ilmiah. ${ }^{4}$

Dalam penelitian ini penulis akan mengamati dan memahami fenomena yang terjadi kemudian memberikan gambaran tentang suatu gejala yang ada mengenai urgensi nilai taksiran terhadap motivasi nasabah dalam transaksi gadai emas.

\section{Pendekatan Penelitian}

Pendekatan penelitian yang digunakan dalama penelitian ini adalah pendekatan ekonomi Islam yaitu salah satu analisis dalam memahami persoalan ekonomi Islam, khususnya memahami persoalan ekonomi yang terkait dengan pembiayaan.

\section{Data dan Sumber Data}

Data adalah sesuatu yang digunakan atau dibutuhkan dalam penelitian dengan menggunakan parameter tertentu yang telah ditentukan. Sumber data penelitian terdiri atas dua yaitudapat menggunakan sumber primer dan sumber sekunder. Pada penelitian ini penulis menggunakan data primer. Data primer adalah sumber data yang langsung memberikan data kepada pengumpul data. ${ }^{5}$ Data primer yang digunakan dalam penelitian ini, diperoleh secara langsung dari

\footnotetext{
${ }^{3}$ Margono, Metode Penelitian Pendidikan (Cet. I; Jakarta: PT. Rineka Cipta, 1997), h 36

${ }^{4}$ Subandi, "Deskripsi Kualitatif sebagai Satu Metode dalam Penelitian Pertunjukanm, Jurnal Hasmonia, Vo. II, No. 2/ Desember 2005, h. 176.

${ }^{5}$ Sugiyono, Metode Penelitian Kuantitatif Kualitatif dan $R \& D$ (Cet. 21; Bandung: Alfabeta, 2014), h. 225. 
objek/ subjek penelitian. Data yang diperoleh dari jawaban informan yang dilengkapi dengan hasil wawancara dari pihak yang berkompeten memberikan informasi sebagai pelengkap dan alat konfirmasi data.

4. Instrumen Penelitian

Adapun instrument penelitian yang digunakan pada penelitian ini yaitu berupa daftar/ lembar pertanyaan/ pedoman wawancara atau interview karena menggunakan metode pengumpulan data yang berupa wawancara atau interview.

5. Teknik Pengumpulan Data

Dalam mengumpulkan data untuk penelitian ini, teknik pengumpulan data yang digunakan sebagai berikut:

a. Studi Pustaka

Studi pustaka adalah instrumen yang digunakan untuk mengumpulkan data-data dengan menelusuri berbagai jenis kepustakaan untuk memperoleh berbagai teori, konsep, dalil-dalil, variabel, hubungan variabel, hasil-hasil penelitian terdahulu yang terkait dengan materi kajian serta data-data sekunder sebagai langkah awal kegiatan penelitian. ${ }^{6}$ Dalam penelitian ini, studi pustaka digunakan untuk memperoleh data-data secara tertulis yang terkait dengan permasalahan yang menunjang dalam penelitian ini.

b. Wawancara

Wawancara adalah percakapan dengan maksud tertentu. Percakapan ini dilakukan oleh dua pihak, yaitu pewawancara (interviewer) yang mengajukan pertanyaan dan terwawancara (interviewee) yang memberikan jawaban atas pertanyaan itu. ${ }^{7}$

Wawancara/ interview, yaitu peneliti mengadakan tanya jawab langsung untuk mendapatkan informasi yang berkaitan dengan penelitian ini. Untuk keperluan penelitian ini, peneliti mengadakan tanya jawab langsung kepada nasabah gadai emas yang berulang kali melakukan transaksi gadai di lembagalembaga gadai.

${ }^{6}$ S. Nasution, Metodologi Research Penelitian Ilmiah, (Jakarta: Bumi Aksara, 2002), h. 61.

${ }^{7}$ Lexy J. Moleong, Metodologi Penelitian Kualitatif, Ed. Revisi (Cet. 22; Bandung: PT Remaja Rosdakarya, 2004), h. 186. 


\section{Teknik Analisis Data}

Untuk menganalisis data yang telah dikumpulkan ditemph teknik analisis deskriptif. Adapun teknik analisis deskriptif bertujuan menggambarkan, meringkaskan berbagai kondisi, situasi, atau fenomena realitas social yang ada di masyarakat yang menjadi obyek penelitian, dan berupaya menarik realitas itu ke permukaan sebagai suatu ciri, karakter, sifat, model, tanda, atau gambaran tentang kondisi, situasi, ataupun, fenomena tertentu. ${ }^{8}$ Analisis deskriptif dalam penelitian ini yaitu mendeskripsikan urgensi nilai taksiran terhadap motivasi nasabah dalam transaksi gadai emas.

\section{HASIL PENELITIAN DAN PEMBAHASAN}

\section{Ketetapan Nilai Taksiran sebagai Pertimbangan dalam Transaksi Gadai Emas Syariah}

Nilai taksiran emas adalah nilai emas yang diagunkan nasabah kepada bank atau pihak pegadaian. Besarnya nilai taksiran ini dipengaruhi oleh dua faktor yakni dari berat emas/ perhiasan yang akan digadaikan serta kadar (karat) dari emas/ perhiasan yang akan digadaikan. Umumnya nilai taksiran tidak sama dengan harga pasar, selain itu jumlah pinjaman yang diberikan juga lebih kecil dari nilai taksiran barang gadai, hal ini dilakukan untuk mencegah munculnya kerugian besarnya nilai taksiran ini akan menjadi landasan bagi bank dalam menentukan besarnya jumlah pinjaman yang akan diberikan kepada nasabah. ${ }^{9}$

Semakin besar nilai taksiran yang diberikan bank terhadap emas/ perhiasan yang akan dijaminkan maka semakin besar pula pinjaman yang dapat diperoleh nasabah demikian pula sebaliknya. Hal ini akan menjadi salah satu pertimbangan nasabah dalam menggadaikan emas/ perhiasannya di bank maupun pegadaian, dapat dilihat dari hasil wawancara beberapa nasabah gadai emas yaitu:

${ }^{8}$ Burham Mungim, Penelitian Kualitatif, Komunikasi, Ekonomi, Kebijakan Publik, dan IImu Sosial lainnya, (Jakarta: Prenada Media Group, 2008), h. 69.

9 Arifah afriana," Pengaruh Nilai Taksiran dan Biaya ljarah terhadap Keputusan Nasabah Melakukan Gadai Emas...., h. 10. 
Menurut Vivi Sasnita yang telah melakukan transaksi gadai di Bank Syariah Mandiri KC Bone mengatakan bahwa ketetapan nilai taksiran yang diberikan Bank Syariah Mandiri KC Bone sudah sesuai dengan barang yang digadaikan. Nilai taksiran yang diberikan BSM lebih rendah dibanding tempat gadai lainnya. Meskipun nilai taksiran yang diberikan BSM rendah akan tetapi biaya pemeliharaan/ titipan yang diberikan sedikit. ${ }^{10}$

Hal ini senada juga dikatakan oleh Zakia Rulmadani mengatakan bahwa kesesuaian nilai taksiran yang diberikan Bank Syariah Mandiri KC Bone terhadap emas/ perhiasan yang digadaikan sudah sesuai. Namun untuk penetapan nilai taksiran nasabah masih merasa kurang puas. Menurut nasabah nilai taksiran yang diberikan oleh pihak Bank Syariah Mandiri KC Bone terhadap emas/ perhiasan relatif lebih rendah dibandingkan tempat lain. Meskipun demikian, rendahnya nilai taksiran tersebut tidak menjadi kendala dan tetap memilih untuk menggadaikan emas di Bank Syariah Mandiri. ${ }^{11}$

Berdasarkan data hasil wawancara menunjukkan bahwa ketetapan nilai taksiran Bank Syariah Mandiri KC Bone lebih rendah dibanding lembaga gadai lainnya. Meskipun nilai taksiran rendah akan tetapi tingkat biaya pemeliharaan yang diberikan sedikit sehingga hal ini menjadi pertimbangan nasabah dalam menggadaikan emasnya dikarenakan biaya pemeliharaan yang diberikan tersebut sesuai dengan kebutuhan nasabah dan tentu tidak menyulitkan nasabah karena Bank Syariah Mandiri KC Bone memberikan biaya pemeliharaan/ titipan yang lebih rendah dibanding dengan lembaga gadai lainnya.

Biaya pemeliharaan dan sewa lembaga keuangan dalam sistem gadai syariah biasa disebut dengan biaya ujrah, biaya ini biasanya di hitung per 10 hari. Dalam hal ini untuk biaya administrasi dan ujrah tidak boleh ditentukan berdasarkan 2018.

${ }^{10}$ Vivi Sasnita, Nasabah Bank Syariah Mandiri KC Bone," Wawancara “ Tanggal 17 September September 2018.

11 Zakia Rulmdani, Nasabah Bank Syariah Mandiri KC Bone," Wawancara " Tanggal 19 
jumlah pinjaman tetapi berdasarkan taksiran harga barang yang digadaikan. Sedangkan besarnya jumlah pinjaman itu sendiri tergantung dari nilai jaminan yang diberikan, semakin besar nilai barang maka semakin besar pula jumlah pinjaman yang diperoleh nasabah. ${ }^{12}$

Menurut Asma yang telah melakukan transaksi gadai di UPC Ahmad Yani mengatakan bahwa kesesuaian nilai taksiran yang diberikan UPC Ahmad Yani terhadap emas/ perhiasan yang digadaikan nasabah sudah sesuai. Ketetapan nilai taksiran yang diberikan UPC Ahmad Yani lebih tinggi dibanding tempat gadai lain. ${ }^{13}$

Hal ini senada juga dikatakan oleh Bungatang bahwa nilai taksiran yang ditetapkan oleh UPC Bone lebih tinggi dibanding tempat lain akan tetapi bunga yang diberikan tinggi. Meskipun demikian, tingginya bunga yang diberikan pihak pegadaian tidak menjadi kendala bagi nasabah untuk tetap menggadaikan emas/ perhiasannya di UPC Bone. ${ }^{14}$

Berdasarkan data hasil wawancara menunjukkan bahwa nilai taksiran yang ditetapkan Pegadaian Konvensional menjadi pertimbangan nasabah menggadaikan emasnya karena ketetapan nilai taksirannya relatif tinggi dibanding tempat gadai lainnya dan tingkat bunga yang diberikan tinggi. Dalam hal ini meskipun tingkat bunga yang diberikan oleh pihak pegadaian konvensional tinggi tidak menjadi kendala bagi nasabah untuk menggadaikan emasnya karena nasabah akan mendapatkan pinjaman yang tinggi. Dimana hal ini sesuai dengan kebutuhan nasabah sendiri.

Menurut Haslindah, S. Hi nilai taksiran yang ditetapkan Pegadaian Unit Pelayanan Syariah Bone sudah sesuai dengan emas yang digadaikan. Nasabah tertarik menggadaikan emasnya karena nilai taksiran yang diberikan tinggi dan di sisi lain biaya penitipannya sedikit. Hal ini menjadi

12 Arifah afriana," Pengaruh Nilai Taksiran dan Biaya ljarah terhadap Keputusan Nasabah Melakukan Gadai Emas...., h. 4.

${ }^{13}$ Asma, Nasabah UPC Ahmad Yani," Wawancara “ Tanggal 24 September 2018.

${ }^{14}$ Bungatang, Nasabah UPC Watampone," Wawancara “ Tanggal 24 September 2018. 
pertimbangan nasabah untuk tetap menggadaikan emas/ perhiasannya di Pegadaian Unit Pelayanan Syariah Bone. ${ }^{15}$

Berdasarkan data hasil wawancara menunjukkan bahwa nilai taksiran yang ditetapkan Pegadaian Unit Pelayanan Syariah Bone menjadi pertimbangan nasabah menggadaikan emasnya. Melihat nilai taksiran yang diberikan jauh lebih besar sehingga jumlah pinjaman lebih tinggi dan tingkat bunga atau pemeliharaan barang gadai lebih rendah. Hal ini menjadi pertimbangan bagi nasabah karena melihat kebutuhan yang tinggi dan pembayaran biaya pemeliharaan rendah yang sesuai dengan kemampuan nasabah.

Nilai taksiran yang tinggi menjadi tolok ukur nasabah menggadaikan emasnya di lembaga gadai syariah. Menurut Rambat Lupiyoadi dan Hamdani, nilai taksiran yang tinggi mampu mendorong keputusan nasabah menggunakan jasa gadai. Nasabah akan merespon positif apabila nilai yang dihasilkan produk mampu memenuhi manfaat bagi kebutuhannya. ${ }^{16} \mathrm{Hal}$ ini sejalan dengan hasil wawancara yang telah dilakukan terhadap beberapa nasabah gadai yang berulang kali melakukan transaksi gadai emas di lembaga gadai baik syariah maupun konvensional. Dapat dinyatakan bahwa nilai taksiran menjadi pertimbangan bagi nasabah dalam melakukan transaksi gadai emas di Bank Syariah Mandiri KC Bone, UPC Ahmad Yani dan Pegadaian Unit Pelayanan Syariah Bone. Lembaga gadai memiliki ketetapan nilai taksiran tersendiri dalam menarik minat nasabah. Tinggi rendahnya nilai taksiran yang ditetapkan masing-masing lembaga gadai berpengaruh terhadap jumlah pinjaman yang nasabah dapatkan. Semakin tinggi nilai taksiran emas maka semakin tinggi pula pinjaman yang diperoleh nasabah, begitupun sebaliknya. Jika nilai taksiran yang diberikan rendah, maka nasabah akan mencari lembaga yang taksirannya lebih tinggi untuk memenuhi kebutuhan. Sehingga nilai taksiran menjadi pertimbangan nasabah memilih sebuah lembaga gadai untuk melakukan transaksi gadai emas.

\section{Nilai Taksiran dan Motivasi Nasabah dalam Transaksi Gadai Emas Syariah}

\footnotetext{
${ }^{15}$ Haslindah, S.Hi, Nasabah UPS Bone," Wawancara " Tangga 22 September 2018.
}

${ }^{16}$ Rambat Lupiyoadi dan Hamdani, Manajemen Pemasaran Jasa....., h. 70-71. 
Penetapan nilai taksiran yang relatif lebih tinggi dan kompetitif yang diterapkan oleh pegadaian maupun bank syariah akan mampu memotivasi nasabah menggunakan produk pembiayaan gadai emas syariah. Hal ini didukung oleh hasil penelitian yang pernah dilakukan oleh Nafila yang menyimpulkan bahwa nilai taksiran berpengaruh positif dan siginifikan terhadap motivasi nasabah dalam menggadaikan emas di Unit Gadai Bank Syariah Mandiri. Artinya, semakin baik tingkat kesesuaian nilai taksiran terhadap emas/ perhiasan yang digadaikan oleh nasabah memotivasi nasabah untuk menggadaikan emas/ perhiasan di lembaga tersebut akan semakin tinggi. ${ }^{17}$

Motivasi secara umum dapat didefinisikan sebagai kesediaan untuk mengeluarkan tingkat upaya yang tinggi untuk tujuan-tujuan yang hendak dicapainya, yang dikondisikan oleh kemampuan upaya untuk memenuhi kebutuhan individual. Motivasi membuat seseorang memulai melaksanakan dan mempertahankan kegiatan tertentu. Motivasi akan kelihatan atau akan tampak melalui perilaku seseorang yang dapat dilihat atau diamati. ${ }^{18}$

Motivasi nasabah merupakan dorongan nasabah untuk melakukan sesuatu dan untuk memutuskan memilih sesuatu. Dalam hal ini terkait motivasi nasabah dalam menggadaikan emasnya untuk memperoleh pinjaman sesuai dengan nilai taksiran yang ditetapkan oleh masing-masing lembaga gadai. Antara nilai taksiran dan motivasi nasabah merupakan dua elemen penting yang berkaitan satu sama lain. Fakta di lapangan, masyarakat yang akan mengajukan pembiayaan selalu menginginkan dana yang tinggi. Kondisi yang demikian tidak dapat dihindari dan paradigma ini sudah tertanam pada sebagian besar masyarakat. Namun demikian, pegadaian maupun bank syariah memiliki ukuran atau batasan tertentu dalam hal penaksiran dari agunan yang dijaminkan nasabah. Dalam hal ini, nilai taksiran berperan penting dalam memotivasi nasabah untuk melakukan transaksi gadai emas

17 Nafila Baladraf, Pengaruh Nilai Taksiran terhadap Motivasi Nasabah dalam Menggadaikan Emas di Unit Gadai Bank Syariah Mandiri Cabang Gorontalo," Skripsi, Fakultas Ekonomi dan Bisnis Universitas Negeri gororntalo, 2013, h. 46.

18 Nugroho, "Perilaku Konsumen: Perspektif Kontemporer Pada Motif, Tujuan dan Keinginan Konsumen", h. 26. 
di suatu lembaga gadai, sebagaimana yang diungkapkan oleh Vivi Sasnita selaku nasabah gadai emas Bank Syariah Mandiri KC Bone:

Nilai taksiran emas berperan penting dalam memotivasi nasabah karena nilai taksiran menjadi acuan bagi nasabah dalam memperoleh pinjaman. Dengan adanya nilai taksiran yang diberikan pihak gadai, maka nasabah akan mengetahui seberapa besarnya pinjaman yang akan didapatkan. ${ }^{19}$

Nilai taksiran yang tinggi mampu mendorong keputusan nasabah menggunakan jasa gadai emas. Nasabah akan merespon positif apabila nilai yang dihasilkan dari produk dan jasa mampu memenuhi manfaat bagi kehidupannya. ${ }^{20}$ Selain itu nilai taksiran sebagai layanan pihak lembaga gadai kepada masyarakat yang ingin mengetahui karat dan kualitas harta perhiasan emas, berlian dan batu permata, baik untuk keperluan investasi ataupun keperluan bisnis dengan biaya yang relatif terjangkau. Sebagaimana yang dikatakan Haslindah S.Hi bahwa:

Dengan adanya nilai taksiran ini memudahkan masyarakat mengetahui tentang karat dan kualitas suatu barang berharga miliknya, sehingga tidak mengalami kebimbangan atas nilai pasti perhiasan yang dimilikinya. ${ }^{21}$

Berdasarkan uraian tersebut, dapat dinyatakan bahwa nilai taksiran emas berperan penting dalam memotivasi nasabah untuk menggadaikan emas di lembaga gadai. Nilai taksiran menjadi acuan bagi nasabah dalam memperoleh pinjaman. Dengan adanya nilai taksiran yang diberikan pihak lembaga gadai, maka nasabah akan mengetahui seberapa besarnya pinjaman yang akan didapatkan. Selain itu nilai taksiran memudahkan masyarakat mengetahui tentang karat dan kualitas suatu barang berharga miliknya.

\section{KESIMPULAN DAN SARAN}

${ }^{19}$ Vivi Sasnita, Nasabah Bank Syariah Mandiri KC Bone," Wawancara " Tanggal 17 September 2018.

20 Rambat Lupiyoadi dan Hamdani, Manajemen Pemasaran Jasa, (Jakarta: Salemba Empat, 2009), h. 70-71.

${ }^{21}$ Haslinda, Nasabah UPS Bone," Wawancara “ Tangga 22 September 2018. 


\section{Kesimpulan}

Berdasarkan hasil analisis dan pembahasan diatas, maka ditarik kesimpulan sebagai berikut :

a. Nilai taksiran menjadi pertimbangan bagi nasabah dalam melakukan transaksi gadai emas di lembaga gadai yang memiliki ketetapan nilai taksiran yang tinggi. Nilai taksiran yang tinggi berpengaruh terhadap jumlah pinjaman yang nasabah dapatkan sehingga nasabah menggadaikan emasnya di lembaga gadai tersebut. Namun tidak hanya nilai taksiran yang menjadi pertimbangan karena beberapa nasabah gadai emas memilih lembaga gadai untuk menggadaikan emasnya berdasarkan biaya pemeliharaan yang relatif rendah. Dalam hal ini membuktikan bahwa bukan hanya nilai taksiran yang menjadi pertimbangan nasabah melakukan transaksi gadai emas tetapi ada beberapa pertimbangan lain seperti biaya pemeliharaan.

b. Nilai taksiran emas berperan penting dalam memotivasi nasabah untuk menggadaikan emas di lembaga gadai. Nilai taksiran menjadi acuan bagi nasabah dalam memperoleh pinjaman. Dengan adanya nilai taksiran yang diberikan pihak lembaga gadai, maka nasabah akan mengetahui seberapa besarnya pinjaman yang akan didapatkan.

\section{Saran}

Berdasarkan kesimpulan diatas, maka penulis memberikan saran-saran sebagai berikut:

1. Lembaga pembiayaan gadai emas harus mampu mengembangkan berbagai produk pilihan berdasarkan nilai taksiran dan juga biaya pemeliharaan sehingga nasabah dapat memilih produk yang menjadi kebutuhan. Karena setiap nasabah memiliki kebutuhan yang berbeda ketika akan melakukan kegiatan gadai emas.

2. Pada pembiayaan gadai emas sebaiknya menentukan nilai taksiran sesuai dengan apa yang diharapkan oleh nasabah sehingga nasabah memilih lembaga gadai tersebut sebagai tempat untuk menggadaikan emasnya. 


\section{DAFTAR PUSTAKA}

Afriana, Arifah." Pengaruh Nilai Taksiran dan Biaya ljarah terhadap Keputusan Nasabah Melakukan Gadai Emas di Pegadaian Syariah Cabang Abdullah Dg. Sirua Makassar, Skripsi, UIN Alauddin Makassar, 2016.

Asma. Nasabah UPC Ahmad Yani,” Wawancara “ Tanggal 24 September 2018.

Baladraf, Nafila. Pengaruh Nilai Taksiran terhadap Motivasi Nasabah dalam Menggadaikan Emas di Unit Gadai Bank Syariah Mandiri Cabang Gorontalo," Skripsi, Fakultas Ekonomi dan Bisnis Universitas Negeri gororntalo, 2013.

Bukhori, Shahih al-Bukhori, Hadis No. 2373. Jil. II Beirut al-Yamamah: Dar Ibnu Katsir, 1987.

Bungatang. Nasabah UPC Watampone," Wawancara “ Tangga 24 September 2018.

Damanhur, Leni Darwina. " Pengaruh Jumlah Taksiran dan Uang Pinjaman terhadap Laba Bersih Pada Perum Pegadaian Syari'ah Kota Lhokseumawe", Jurnal Aplikasi Manajemen, No. 2, Vol.4 Maret 2011.

Departemen Agama RI, Al-Qur'an Al-Karim dan Terjemahnya, (Semarang: PT. Karya Toha Putra Semarang, 2002), h. 851.

Faridatun, Sa'adah. Analisis Pemasaran Produk Gadai Syariah dalam Upaya Menarik Minat Nasabah pada Pegadaian Syariah Cabang Dewi Sartika, Fakultas Syariah dan Hukum Uin Sumatera Utara Jakarta, 2011.

Hadi, Satria Lubis. Total Motivation, Cet. V: Yogyakarta; Pro You, 2009.

Haslinda. Nasabah UPS Bone," Wawancara “ Tangga 19 September 2018.

http://www.Syariahmandiri.com/. Diakses tanggal 27 April 2017, Pukul 15.20 WITA. https://academia.edu/6952113/Makalah Ekonomi Syariah. Diakses Tanggal 3 Oktober 2018, Pukul 10.23 WITA.

https://ekonomikeadilan.wordpress.com/2011/08/05/kajian-fiqh-muamalah-tentanggadai-emas-syariah/.Diakses Tanggal 3 Oktober 2018, Pukul 10.46 WITA.

Huda, Nurul. Lembaga Keuangan Islam, Jakarta: Kencana, 2010.

Irfan, Andi. Suatu Tinjauan Islc 47 aktik "Boroh" (Pegadaian) Mengatasi Masalah dengan Masalah," Jurnal ansi Universitas Jember. 
Irwoana, Fanir. "Strategi Pemasaran Gadai Emas pada Produk Rahn PT. Bank Aceh Syariah Cabang S. Parman," Skripsi, Fakultas Ekonomi dan Bisnis Islam UIN Sumatera Utara, 2017.

Leni, Damanhur Darwina. " Pengaruh Jumlah Taksiran dan Uang Pinjaman terhadap Laba Bersih Pada Perum Pegadaian Syari'ah Kota Lhokseumawe", Jurnal Aplikasi Manajemen, No. 2, Vol.4 Maret 2011.

Lupiyoadi, Rambat Hamdani. Manajemen Pemasaran Jasa, Jakarta: Salemba Empat, 2009.

Majalah Internal BSM, ETHIC Jakarta, Edisi 12 Spesial Milad/ November 2015.

Mardani, Aspek Hukum Lembaga Keuangan Syariah di Indonesia, Cet.I; Jakarta: Kencana, 2015.

Margono. Metode Penelitian Pendidikan, Cet. I; Jakarta: PT. Rineka Cipta, 1997.

Moleong. Lexy J.. Metodologi Penelitian Kualitatif, Ed. Revisi, Cet. 22; Bandung: PT Remaja Rosdakarya, 2004.

Mungim, Burham. Penelitian Kualitatif, Komunikasi, Ekonomi, Kebijakan Publik, dan IImu Sosial lainnya, Jakarta: Prenada Media Group, 2008.

Passe, Longginus. Pengaruh Kualitas Pelayanan Terhadap Keputusan Nasabah Studi pada PT. Bank Papua Cabang Daerah Istimewa Yogyakarta," Skripsi", Program Studi Manajemen Fakultas Ekonomi Universitas Sanata Dharma, Yogyakarta, 2016.

Perum Pegadaian, Company Profile, Jakarta, 2007. 